HISTORIA: Jurnal Pendidik dan Peneliti Sejarah, 5(1), 65-80. https://doi.org/10.17509/historia.v5i1.36374.

Available online at HISTORIA; Jurnal Pendidik dan Peneliti Sejarah
Journal homepage: https://ejournal.upi.edu/index.php/historia

\title{
ANALISIS TEMUAN BENDA-BENDA PENINGGALAN SEJARAH DI SUNGAI MUSI SEBAGAI SUMBER PEMBELAJARAN SEJARAH
}

\author{
Liamilatul Rohmah, Kabib Sholeh, Wandiyo \\ Pendidikan Sejarah, FKIP, Universitas PGRI palembang \\ Correspondence: liamilatulr@gmail.com.
}

To cite this article: Rohmah, L., Sholeh, K., \& Wandiyo. (2022). Analisis temuan benda-benda peninggalan sejarah di sungai musi sebagai sumber pembelajaran sejarah. HISTORIA: Jurnal Pendidik dan Peneliti Sejarah, 5(1), 65-80. https://doi. org/10.17509/historia.v5i1.36374..

Naskah diterima : 6 Juli 2021, Naskah direvisi : 20 September 2021, Naskah disetujui : 20 Desember 2021

\begin{abstract}
The existence of the Musi River caused the city of Palembang to be divided into two parts, namely across Ilir and Seberang Ulu which had long been the backbone of water transportation in Palembang, as in the days of the Srivijaya kingdom, the Musi River was used as a trade route which made the Sriwijaya kingdom one of the largest maritime empires. The purpose of this study is to analyze the findings of historical relics in the Musi River which will later be used as a source of historical learning. In this writing, the researcher uses a qualitative descriptive research method, which starts from the activities of observation, documentation, interviews, and literature study. On the Musi River, you can find historical relics from various periods such as the Srivijaya, Sultanate, and Colonial eras. As for the relics of the Srivijaya era such as the Sriwijaya Dragon Sword, Tin Letter, Goods Money, Ceramics, Beads, Jars, Tarakota Jugs, objects from the Sultanate such as Coins, Machetes, Ceramics in the form of Jars, as well as during the Colonial period such as Money Coins, Ink Containers, Herbal Bottles, Alcohol Bottles. Every object found has values, namely political values and power, struggle and strength, economics and technology, and aesthetic values.
\end{abstract}

Keywords: Historical relics; learning resource; musi river.

\begin{abstract}
Abstrak
Pada zaman kerajaan Sriwijaya Sungai Musi dijadikan sebagai jalur perdagangan yang menjadikan kerajaan Sriwijaya merupakan salah satu kerajaan maritim terbesar di Nusantara. Tujuan penelitian ini adalah untuk menganalisis temuan benda-benda peninggalan sejarah di Sungai Musi yang nantinya akan digunakan sebagai sumber pembelajaran sejarah. Dalam penulisan ini peneliti menggunakan metode penelitian Deskriptif Kualitatif, yang dimulai dari kegiatan observasi, dokumentasi, wawancara, dan studi pustaka. Di Sungai Musi banyak ditemukan benda-benda peninggalan sejarah dari berbagai masa seperti masa Kerajaan Sriwijaya, Kesultanan, dan Kolonial. Adapun benda benda peninggalan masa Sriwijaya seperti Pedang Naga Sriwijaya, Surat Timah, Uang Barang, Keramik, Manik-manik, Guci, Kendi Tarakota, benda-benda masa Kesultanan seperti Mata Uang Koin, Golok, Keramik berbentuk Guci, serta pada masa Koloinial seperti Uang Koin, Wadah Tinta, Botol Jamu, Botol Akohol. Setiap benda-benda yang ditemukan memiliki nilai-nilai yaitu nilai politik dan kekuasaan, perjuangan dan kekuatan, ekonomi dan teknologi, serta nilai estetika.
\end{abstract}

Kata kunci: Benda peninggalan sejarah; sumber pembelajaran; sungai musi.

HISTORIA: Jurnal Pendidik dan Peneliti Sejarah, p-issn:2620-4789 | e-issn:2615-7993 


\section{PENDAHULUAN}

Sejarah berkaitan dengan segala sesuatu yang telah terjadi dimasa lampau, sejarah selalu dipenuhi dengan misteri bagi sebagian remaja dan siswa, hal ini terjadi karena sejarah hanya dapat dilihat dari peninggalanpeninggalan maupun bukti otentik lainnya yang kurang begitu jelas (Khoirotun, Fianto, \& Riqqoh, 2014). Indonesia merupakan negara kepulauan yang besar, sejak dahulu Indonesia memiliki kebudayaan dan sejarah yang telah ada dari zaman Pra-aksara hingga masa kemerdekaan (Ryan, Akbar, \& Andryani, 2016). Salah satu pulau yang ada di Indonesia adalah pulau Sumatera, dan Sumatera Selatan adalah salah satu provinsi di pulau tersebut.

Sumatera Selatan sejak berabad lalu dikenal dengan sebutan Bumi Sriwijaya, yang beribukota di Palembang. Secara geografis provinsi Sumatera Selatan berbatasan dengan Jambi di utara, provinsi Kep. Bangka Belitung di timur, provinsi Lampung di Selatan dan provinsi Bengkulu di barat. Karena Sumatera Selatan khususnya Kota Palembang saat itu menjadi pusat Kerajaan Sriwijaya menjadikan tempat ini terdapat banyak temuan benda-benda sejarah dan budaya, salah satunya di tepian Sungai Musi.

Sungai Musi menggambarkan citra Palembang sebaga kota sungai atau air. Keberadaan sungai musi ini menyebabkan kota Palembang terbelah menjadi dua bagian yaitu Seberang Ilir dan Seberang Ulu (Husnul, 2014). Sungai Musi sejak dahulu telah menjadi tulang punggung transportasi air di Palembang (Prakoso, 2018), seperti pada zaman kerajaan Sriwijaya sungai Musi dijadikan sebagai jalur perdagangan yang menjadikan kerajaan Sriwijaya merupakan salah satu kerajaan maritime terbesar di Nusantara. Nusantara sendiri dari dulu penduduknya dikenal sebagai pelayar hebat dalam mengarungi lautan luas (Sholeh, 2018). Karena peran Sungai Musi yang besar dalam trasportasi dan perdagangan pada zaman dahulu, tidak heran apabila banyak ditemukannya benda-benda peninggalan sejarah di tepiannya.

Temuan peninggalan benda-benda sejarah di Sungai Musi merupakan aset berharga dan merupakan kekayaan budaya, hal ini karena benda-benda tersebut mengandung makna nilai dari budaya nenek moyang untuk kenangan sepanjang masa (Wartha, 2016), yang dapat dikembangkan sebagai media pembelajaran sejarah di sekolah. Benda-benda Peninggalan tersebut ditemukan bukan tanpa kesengajaan melainkan dicari oleh kelompok masyarakat sekitar, yang mana bendabenda tersebut menjadi barang koleksi.

Peninggalan sejarah mempunyai nilai sejarah yang masih ada sampai saat ini, berdasarkan jenis wujudnya peninggalan sejarah dapat dikelompokan menjadi empat macam, yaitu bangunan, benda-benda, tulisan dan karya sastra (Khoirotun, 2014). Benda-benda disini seperti fosil, artefak, arca dan patung, yang semuanya memiliki maknanya masing-masing, hal tersebut perlu diketahui oleh peserta didik sebagai ilmu pengetahuan.

Pendidikan pada dasarnya dikembangkan untuk mempersiapkan generasi bangsa Indonesia menjadi warga negara yang aktif dan produktif (Hasan, 2019). Dalam UU No 20 tahun 2013 tentang Sistem Pendidikan Nasional, menerangkan bahwasanya pendidikan adalah upaya sadar dan terencana dalam proses pembimbingan dan pembelajaran bagi individu agar tumbuh berkembang menjadi bertanggung jawab, kreatif, berilmu, sehat dan berakhlak mulia. Sistem Pendidikan Nasional mengemban misi untuk membangun bangsa dengan jati diri yang utuh, sehingga pendidikan nasional harus bermutu dengan selalu menanamkan pendidikan karakter (Suyadi, 2013). Untuk menciptakan pendidikan yang bermutu dibutuhkan tenaga pengajar yang professional, media pembelajaran yang sesuai serta faktor pendukung yang lain.

Perkembangan ilmu pengetahuan dan teknologi yang berkembang pesat dapat mempengaruhi dalam penyusunan strategi pembelajaran (Novitasari \& Hanif, 2017). Sumber pembelajaran merupakan sarana yang penting dalam pembelajaran dan pengajaran. Guru juga memiliki keharusahan untuk mencari dan memanfatkan berbagai macam sumber guna mendapatkan alat bantu yang tepat dan melengkapi apa yang sudah tersedia, yang dapat digunakan untuk menambah informasi, memperluas konsep dan membangkitkan minat belajar peserta didik (Kochhar, 2008). Sumber pembelajaran digunakan untuk mendukung dan memudahkan proses pembelajaran sehingga dapat mempermudah mencapai tujuan dalam pembelajaran (Slameto, 1991). Dari hal tersebut dapat dikatakan bahwa sumber pembelajaran sejarah merupakan pendukung dari berbagai sumber yang ada dalam pelajaran sejarah.

Dengan adanya perkembangan teknologi yang semakin maju guru dapat menggunakan berbagai media sesuai dengan kebutuhan dan tujuan dalam pembelajaran. Media pembelajaran adalah seluruh alat dan bahan yang dipakai untuk tujuan pendidikan yang mana menciptakan kondisi yang memungkinkan siswa memperoleh pengetahuan, keterampilan dan sikap (Sanjaya, 2006), atau secara umum media pembelajaran dapat dikatakan sebagai alat bantu mengajar. Sehingga dalam hal ini media pembelajaran merupakan salah satu komponen yang sangat di perlukan (Ainina, 2014).

Dalam proses pembelajaran, keberhasilan bergantung kepada penggunaan sumber dan media pembelajaran

HISTORIA: Jurnal Pendidik dan Peneliti Sejarah, p-issn:2620-4789 | e-issn:2615-7993 
HISTORIA: Jurnal Pendidik dan Peneliti Sejarah, 5(1), 65-80. https://doi.org/10.17509/historia.v5i1.36374.

yang sesuai, sehingga dalam penyusunannya dipersiapkan dengan tepat dan hati-hati sehingga menimbulkan motivasi positif peserta didik, melibatkan peserta didik, dapat menggambarkan isi subjek dan kinerja individual (Susanto \& Akmal, 2019).

Temuan benda-benda peninggalan sejarah di Sungai Musi Palembang sebenarnya terkumpul sangat banyak, namun temuan tersebut kurang dimanfaatkan sebagai sumber pembelajaran sejarah contohnya seperti pedang yang terdapat pada relief candi Borobudur, cincin, mata uang, macam-macam jenis keramik dari berbagai dinasti, dll, benda-benda tersebut pada saat ini masih dijualbelikan dengan bebas, padahal dalam bendabenda tersebut mengandung nilai-nilai sejarah. Dengan dijadikannya sumber pembelajaran sejarah, temuan benda-benda peninggalan tersebut dapat menambah pengayaan dan pengetahuan khususnya di sekolah. Berdasarkan latar belakang di atas penulis tertarik untuk meneliti temuan benda-benda peninggalan sejarah di Sungai Musi, yang mengangkat judul "Analisis Temuan Benda-Benda Peninggalan Sejarah di Sungai Musi sebagai Sumber Pembelajaran Sejarah".

\section{METODE}

Dalam penulisan ini peneliti menggunakan metode penelitian Deskriptif Kualitatif, dimana dalam penelitiannya menggunakan cara mengumpulkan sumber-sumber secara sistematis (berurutan) dan diperlukan menggunakan sumber data secara mendalam. Penelitian deskriptif kualitatif disampaikan dengan kata-kata yang sesuai menurut responden, apa adanya sesuai dengan pertanyaan penelitiannya, setelah selesai kemudian dilakukan analisis menggunakan dengan kata-kata apa yang melatarbelakangi responden berperilaku (berpikir, berperasaan, dan bertindak) seperti itu tidak seperti lainnya, direduksi, ditriangulasi, disimpulkan (diberi makna oleh peneliti), dan diverifikasi (dikonsultasikan kembali dengan responden). Dalam penelitian kualitatif minimal ada tiga hal yang digambarkan, yaitu karakteristik, kegiatan, atau kejadian-kejadian yang terjadi selama penelitian, dan keadaan lingkungan tempat penelitian berlangsung.

Metode penelitian merupakan cara yang digunakan oleh peneliti dalam mengumpulkan data penelitiannya. Seperti sudah dijelaskan, variasi dimaksud yaitu: angket, wawancara, pengamatan atau observasi, tes, dan dokumentasi. Metode penelitian kualitatif dinamakan sebagai metode baru, karena popularitasnya belum lama, dinamanakan postpositivistik karena berlandaskan pada filsafat postpositivisme. Metode deskriptif kualitatif disebut lebih bersifat seni (kurang terpola), atau juga dapat disebut dengan metode interpretive, hal ini karena data hasil penelitian lebih berkenaan dengan interprestasi terhadap data yang ditemukan di lapangan.

Berdasarkan penjelasan diatas dapat disimpulkan bahwa metode deskriptif kualitatif adalah metode atau cara kerja dalam penelitian yang semata-mata menjelaskan keadaan objek berdasarkan fakta yang ada atau fenomena secara nyata tampak apa adanya. Mengacu pada definisi tersebut, maka dalam penelitian ini akan dijelaskan, analisis temuan benda-benda peninggalan sejarah di Sungai Musi.

\section{PEMBAHASAN}

\section{Sungai Musi Palembang dari Masa ke Masa (Suatu Tinjauan Historis)}

\section{a. Peranan Sungai Musi Masa Sriwijaya}

Kerajaan Sriwijaya merupakan kerajaan-pantai, yaitu sebuah negara perdagangan dan negara yang berkuasa di laut (Burhanuddin, 2003). Kerajaan Sriwijaya merupakan kerajaan maritime besar yang telah dikenal secara luas. Adapun bukti dari keberadaan kerajaan Sriwijaya terdapat dalam berbagi temuan seperti manik-manik, arca, keramik, dan prasati, prasati tersebut meliputi Prasasti Talang Tuo, Prasasti Kedukan Bukit, Prasasti Telaga Batu, Prasasti Kota Kapur, Prasasti Karang Berahi, dan yang lainnya. Prasati Kedukan Bukit menjelaskan tentang perjalanan Dapunta Hyang yang membawa dua puluh ribu tentara untuk melakukan perjalanan suci (Sidhayatra) yang kemudian mendirikan sebuah wanua, wanua sendiri diartikan sebagai kerajaan (Sholeh, 2017).

Kerajaan Sriwijaya dikenal dengan kerajaan maritim yang besar, dan pernah tumbuh sebagai kerajaan maritim terbesar di Asia Tenggara (Burhanuddin, 2003), yang mana hal trersebut tidak lepas dari peran Sungai Musi itu sendiri. Adapun peran sungai Musi pada masa kerajaan Sriwijaya sebagai jalur pelayaran dan perdagangan yang maju. Sebagai jalur pelayaran Kerajaan Sriwijaya melakukan Politik Ekspansi ke wilayah-wilayah bagian, seperti wilayah Melayu di Jambi, pulau Bangka, dan daerah Lampung Selatan, dan usaha penaklukan pulau Jawa, penaklukan di pulau Bangka dikatakan berhubungan dalam penguasaan perdagangan dan pelayaran Internasional di Selat Malaka (Burhanuddin, 2003).

Kerajaan Sriwijaya menguasai pelayaran perdagangan ke Cina dan negeri-negeri barat dengan kekuatan utamanya menguasai daerah Selat Malaka. Dalam pelaksanaan perdagangannya agar tetap menjadi pusat perdagangan kerajaan Sriwijaya memiliki ciri khas 
sendiri yaitu melakukan diplomasi. Untuk menguasai selat Malaka dan mengamankan jalur perdaganganya Kerajaan Sriwijaya memiliki angkatan laut yang kuat (Pradhani, 2017). Bahkan dalam hal ini kerajaan Sriwijaya memiliki hal yang unik untuk mengamankan jalur perdaganganya yaitu dengan menjadikan kepala bajak laut sebagai pengamanan yang nantinya diberikan upeti bagian atau jatah yang telah ditentukan oleh raja kepada mereka, selain itu Kerajaan Sriwijaya juga melakukan hubungan diplomasi dengan Cina dan memberikan upeti sehingga Cina akan membantu Kerajaan Sriwijaya apabila dibutuhkan (Burhanuddin, 2003), dengan pola ini Kerajaan Sriwijaya berhasil mengamankan jalur pelayaran dan perdagangannya.

Politik lain yang di gunakan oleh Kerajaan Sriwijaya dengan menerapkan politik laut yang mana setiap kapal-kapal yang lewat diwajibkan untuk singgah ke pelabuhannya yang dikenal dengan "paksaan menimbun barang”. Selama berlabuh, kapal-kapal dagang tersebut dapat melakukan bongkar muatan, mengambil air minum dan barang bekal lainya, sehingga pelayaran dan perdagangan Kerajaan Sriwijaya tidak pernah sepi (Burhanuddin, 2003). Dengan perdagangan dan pelayaran yang menjadi sektor utama, tentunya membutuhkan pengawasan dari penguasa Kerajaan Sriwijaya secara langsung.

Selain menjadi pusat pelayaran dan perrdagangan negara-negara barat dan Cina Sungai Musi juga sebagai jalur penyebaran Agama Budha di Kerajaan Sriwijaya, hal ini dapat dibuktikan dari catatan I-tsing tahun 671 yang menyatakan bahwa ia berangkat dari Kanton ke India, kemudian singgah di Kerajaan Sriwijaya selama 6 bulan untuk mempelajari tata bahasa Sangsekerta. Selanjutnya selama dua bulan ia singgah di Malaka, dan melanjutkan perjalanan ke India untuk tinggal selama empat tahun. Pada tahun 685, I-tsing kembali ke Sriwijaya selama empat tahun untuk menerjemahkan kitab suci Budha daribahasa Sangsekerta ke bahasa Tionghoa. Dari catatan I-tsing ini kita dapat mengetahui selain sebagai pusat perdagangan Kerajaan Sriwijaya menjadi pusat kegiatan ilmiah agama Budha. Bahkan Sakyakirti seorang guru terkenal, pendeta yang akan ke India dianjurkan untuk belajar terlebih dahulu ke Sriwijaya sekitar satu atau dua tahun. (Burhanuddin, 2003).

\section{b. Peranan Sungai Musi Masa Kesultanan}

Sungai Musi berperan dalam perkembangan peradaban Islam di Palembang. Sebagai urat nadi kehidupan Sungai Musi yang dijadikan sebagai jalur perdagangan menarik perhatian masyarakat bangsa lain untuk datang ke Palembang, diantaranya adalah masyarakat yang beragama Islam. Para pedagang Islam yang datang tersebut menyebargam agama Islam dengan melakukan dakwah kepada setiap penduduk yang dikunjungi. Hasilnya di Palembang agama Islam menjadi mayoritas agama penduduknya. Ajaran Islam yang bercampur dengan kondisi geografis wilayah Palembang memberikan bentuk peradaban Islam yang khas. Dengan peradaban Islam yang berkembang dibidang politik menjadikan Palembang kota dengan Keraton Kesultanan Palembang Darussalam (Farida, Rochmiatun, \& Kalsum, 2019). Pengaruh Sungai Musi terhadap perkembangan Peradaban Islam dapat dilihat dari Masjid Agung, pemukiman dan pemakamam muslim.

Kesultanan Palembang berdiri sejak telah berakhirnya perang Palembang antara Kerajaan Palembang dan VOC (Vereenigde Oost-Indische Compagnie) yaitu pada tahun 1659 dengan kekalahan di pihak Palembang. Sejak saat itu, tahta digantikan oleh Ki Mas Hindi sebagai penguasa baru, dan membangun kembali Palembang diatas puing-puing yang telah hancur (Mahmud, 2008). Keraton Kuto Gawang yang merupakan simbol kekuasaan dan pusat pemerintahan telah dibakar oleh Belanda selama peperangan sehingga Ki Mas Hindi secara berangsur-angsur mengembangkan Palembang kembali dan menumbuhkan dirinya sebagai sultan dengan gelar Sultan Abdulrakman Khalifatul Mukminin Sayidul Imam, dengan Islam sebagai agama negara. Dengan pengangkatan tahta baru Palembang dapat melepaskan diri dari kendali kerajaan Mataram dan mampu berdiri sejajar dengan kerajaan lain di Nusantara. Pada masa setelah pergantian kekuasaam yang digantikan oleh Sultan Mahmud Badaruddin Jayawikrama keadaan Kesultanan Palembang semakin baik dengan memprakasai pengembangan timah Bangka yang mendapatkan keuntungan dari perdagangan (Farida, 2020).

Pada abad XIX Kesultanan Palembang menghadapi konflik, yaitu konflik internal dan Eksternal. Konflik internal tersebut terjadi antara kedua putra, setelah kenaikan tahta putra mahkota yang satu bergelar Sultan Mahmud Badaruddin II dan satunya lagi bergelar Pangeran Adipati, setelah sultan Mahmud Badaruddin II naik tahta Pangeran Adipati merasa iri, bahkan dalam berbagai sumber keiriin tersebut sudah terjadi sebelum kenaikan tahta. Adapaun konflik Kesultanan Palembang secara eksternal adalah perang Palembang yang terjadi antara Kesultanan Palembang dengan pihak Inggris dan Belanda. Perang ini sendiri dipicu oleh adanya konflik yang bermula saat Sultan Badaruddin II menolak permintaan Inggris sebagai penguasa baru menggatikan Belanda yang kalah perang pada 1811. Dan yang paling utama adalah adanya penolakan untuk menyerahkan Pulau Bangka kepada Inggris, seperti yang kita tahu 
HISTORIA: Jurnal Pendidik dan Peneliti Sejarah, 5(1), 65-80. https://doi.org/10.17509/historia.v5i1.36374.

bahwa Bangka kaya akan Timah. Dengan penolakan Sultan Mahmud Badaruddin II terhadap permintaan Inggris, menghadiahkan akibat dikirimnya armada militer dari Batavia (Jakarta Sekarang). Pada saat inilah Sungai Musi memberikan peran menghambat laju musuh, yang diperparah dengan cuaca yang kurang mendukung. Sehingga upaya Inggris untuk mendekati Benteng Borang menjadi sangat sulit. Adapun peperangan antara kedua pihak tidak terjadi karena adanya negoisasi antara pihak Inggris yang diwakili Kapten R. Meares dan Kesultanan Palembang Pangeran Adipati. Hasil dari negoisasi tersebut Pangeran Adipati selaku Pimpinan perang telah menyerahkan Benteng Borang kepada pasukan musuh yang artinya terbukanya Benteng Kuto Besak untuk diduduki (Farida, 2020).

Sungai Musi pada masa Kesultanan Palembang berperan penting sebagai sumber kehidupan masyarakat, dan perlindungan. Sebagai perlindungan dalam hal ini saat terjadi perang antara pihak Inggris dan Belanda yang mana dapat dijadikan sebagai benteng pertahanan. Sungai Musi dengan arusnya yang deras membuatnya sulit untuk dilalui, selain itu dengan adanya perbedaan yang mencolok antara pasang dan surut air, dangkal dan sempit saat kemarau, dan rawa yang sulit untuk ditembus membuat musuh kesulitan untuk menghadapinya dan memerlukan pembiasaan diri dalam hal tersebut. Sungai Musi juga digunakan sebagai tempat penanaman tonggaktonggak kayu yang fungsinya sebagai penghadang musuh, mengalirkan balok kayu dan rakit-rakit api untuk menyerang musuh, menghambat pergerakan atau bahkan menghancurkanya, yang dalam hal ini seperti rusaknya perahu musuh contohnya terjadinya kebocoran kapal atau bahkan kebakaran (Farida, 2020). Meskipun dalam hasil akhirnya kekalahan tetap di pihak Kesultanan Palembang, namun Sungai Musi menjadi pertahanan atau benteng alam yang sangat luar biasa.

Pada masa Kesultanan Palembang, tepi Sungai Musi yang dahulunya sebagai sarana Transportasi dijadikan sebagai pemukiman masyarakat (Wicaksono \& Kusdiwanggo, 2016). Pemukiman masyarakat dan tatanan kota telah dipisahkan oleh cluster tertentu sesuai jabatan, pekerjaan, keahlian, dan etnis penduduknya. Bahkan menurut sumber, pembagian kelompok masyarakat ini sudah ada sejak zaman dahulu namun hanya berdasarkan etnis. Penempatan penduduk asing disuatu tempat tersendiri dimulai ketika keraton dari Kerajaan Palembang masih di Kuto Gawang, yaitu abad ke 17 Masehi dengan wilayah Seberang Ulu yang berada di sisi selatan Sungai Musi ditempati oleh Bangsa Eropa, India, Arab, dan Tionghoa. Adapun contoh pemukiman penduduk asing ini yang masih ada sampai sekarang seperti Kampung Arab dan Kampung Tionghoa. Bahkan pada saat Belanda masuk dan diberikan izin untuk mendirikan loji, para penguasa menempatkannya di muara Sungai Aur (Utomo, 2015).

Perekonomian pada masa Kesultanan Palembang berkembang dengan baik dengan penduduknya yang memiliki pekerjaan sebagai petani, pedagang, nelayan dan perikanan, yang dalam hal ini peran Sungai Musi sangat penting, dengan fakta kondisi geografis sekitar yang memiliki aliran air yang besar. Dengan adaya komoditi utama lada dan timah, karet, serta kopi yang diperdagangkan membuat ekonomi Kesultanan Palembang meningkat.

\section{c. Peranan Sungai Musi Masa Kolonial}

Pada masa kolonial, Sungai Musi berperan sebagai perkembangan peradaban Islam. Peradaban Islam di Palembang dipengaruhi oleh berbagai kebijakan politik Hindia-Belanda. Pada masa ini, sistem Kesultanan Darussalam di hapuskan dan bahkan mengubah fungsi dari Keraton Kuto Besak yang awalnya sebagai alun-alun kota menjadi tangsi militer Belanda untuk pertahanan. Kedatangan kolonial Hindia Belanda ini mengubah berbagai tatanan kota Palembang, bahkan dalam hal ini kolonial Belanda membangun simbol-simbol kolonialisme (Farida, Rochmiatun, \& Kalsum, 2019).

Sungai Musi pada masa ini masih menjadi transportasi untuk pelayaran dan perdagangan, bahkan dengan sistem yang lebih modern, adapun hal yang membuka masyarakat kota asing untuk memberikan wakil-wakil dagangnya di Palembang adalah produksi dan letak kota. Kongsi kapal besar Belanda juga memiliki pemahamaan yang tinggi dalam mengartikan hal ini sehingga pelayaran di Sungai Musi menjadi lebih mudah. Dengan adanya sungai Musi hasil-hasil yang didapat mudah untuk dibawa keluar kota, dan waktu untuk pengiriman menjadi lebih singkat kemana-mana, hal ini juga berlaku apabila aada barang yang dibutuhkan dapat diperoleh dengan mudah dan cepat didapat. Dengan kondisi yang seperti ini menguntungkan para pedagang (Santun, 2010).

Pada masa kolonial pemukiman warga yang mulanya di tepian sungai, berubah di daratan dengan menghadap jalan raya, yang membuat pemukiman ini membelakangi pemukiman di tepian sungai. Dengan dibangunya jalan raya di darat, transportasi juga berpindah, yang awalnya menggunakan transportasi air seperti perahu dan ketek beralih ke transportasi darat. Namun masyarakat pemukiman tepian sungai Musi masih ada dan transportasi air juga masih digunakan. Sungai Musi pada masa ini lebih digunakan sebagai 
transportasi pertambangan, yaitu untuk mengangkut batubara dengan menggunakan perahu tongkang.

\section{d. Peranan Sungai Musi Pasca-Kemerdekaan}

Palembang masa pascakolonial dimulaai dari pengakuan kedaulatan atau disebut era kemerdekaan atau revolusi fisik (Santun, 2010). Setelah pasca kolonial pemerintah kota berusaha mengubah Palembang baru. Akibat dari kolonial ini Palembang yang terkenal dengan sebutan kota air berubah menjadi kota daratan. Untuk membangun identitas dan melekatkan jiwa nasional masyarakat dibangunlah Jembatan Ampera, yang menggambarkan keinginan agar zaman berubah. (Santun, 2010).

Pembangunan Jembatan Ampera adalah sebagai penghubung antara wilayah Ulu dan Ilir dimana sebelum adanya pembangunan jembatan terdapat ketimpangan antara kedua wilayah yang dipisahkan oleh Sungai Musi ini. Ketimpangan tersebut dari berbagai aspek seperti sosial, pendidikan, dan ekonomi, dimana wilayan Ulu-an masih tertinggal dibandingkan wilayah Ilir-an. Pembangunan jembatan ini sebernya sudah lama diisukan, yaitu sejak tahun 1924 namun pada 1960 pendanaan baru dicairkan oleh Soekarno karena adanya dana rampasan Jepang. Pada 1960 inilah akhirnya jembatan mulai dilakukan pembangunan dimana Soekarno meminta agar jembatan tersebut dapat bertahan selama lebih dari 100 tahun dan dikabulkan oleh ahli-ahli Jepang. Jembatan ini akhirnya selesai pembangunannya pada tahun 1995, dan rakyat Palembang menamai jembatan itu dengan "Jembatan Bung Karno", hal ini sebagai rasa terima kasih kepada presiden.

Setelah selesainya pembangunan jembatan kehidupan masyarakat kota Palembang khusunya bagian Ulu-an berubah baik dari segi sosial, ekonomi maupun yang lainya, hal ini dikarenakan sudah adanya penghubung sehinngga memudahkan masyakakat untuk melakukan aktivitasnya dan pergi ke wilayah kota yaitu wilayah Iliran.

Peranan Sungai Musi pasca kemerdekaan masih digunakan sebagai permukiman warga di tepiannya yang dapat dilihat hingga sekarang, dijadikan sebagai sumber mata pencaharian penduduk sekitar yakni menjadi nelayan ataupun perikanan, selain itu Sungai Musi juga dijadikan sebagai alat transportasi sehari hari, dan juga untuk mengangkut batu bara pertambangan dengan menggunakan kapal tongkang. Adapun peran sungai Musi tidak sama lagi dengan zaman dahulu khusunya dalam bidang perdagangan dan pelayaran hal ini terjadi karena adanya sedimentasi dan pendangkalan kedalaman air sehingga kapal-kapal besar tidak dapat lagi melalui sungai Musi.

\section{Benda-benda Kuno Peninggalan Sejarah di Sungai Musi}

\section{a. Benda-Benda Peninggalan Masa Sriwijaya}

Sungai Musi merupakan sungai yang memiliki peranan penting pada masanya yang dimulai sejak zaman Kerajaan Sriwijaya. Sebagai sungai yang sibuk dan ramai oleh lalu lalang perdagangan pada masa lampau, membuat Sungai Musi sekarang memiliki benda harta karun tersembunyi didalamnya. Hal ini dapat dilihat dari banyaknya benda-benda peninggalan sejarah yang ditemukan di dasar sungai. Benda yang ditemukan memiliki banyak ragam seperti keramik, koin, uang barang, pedang, dan lain-lain.

Untuk mendapatkan benda tersebut diperlukan upaya penyelaman, yang dilakukan oleh orang-orang sekitar Sungai Musi dari berbagai kalangan usia, bahkan

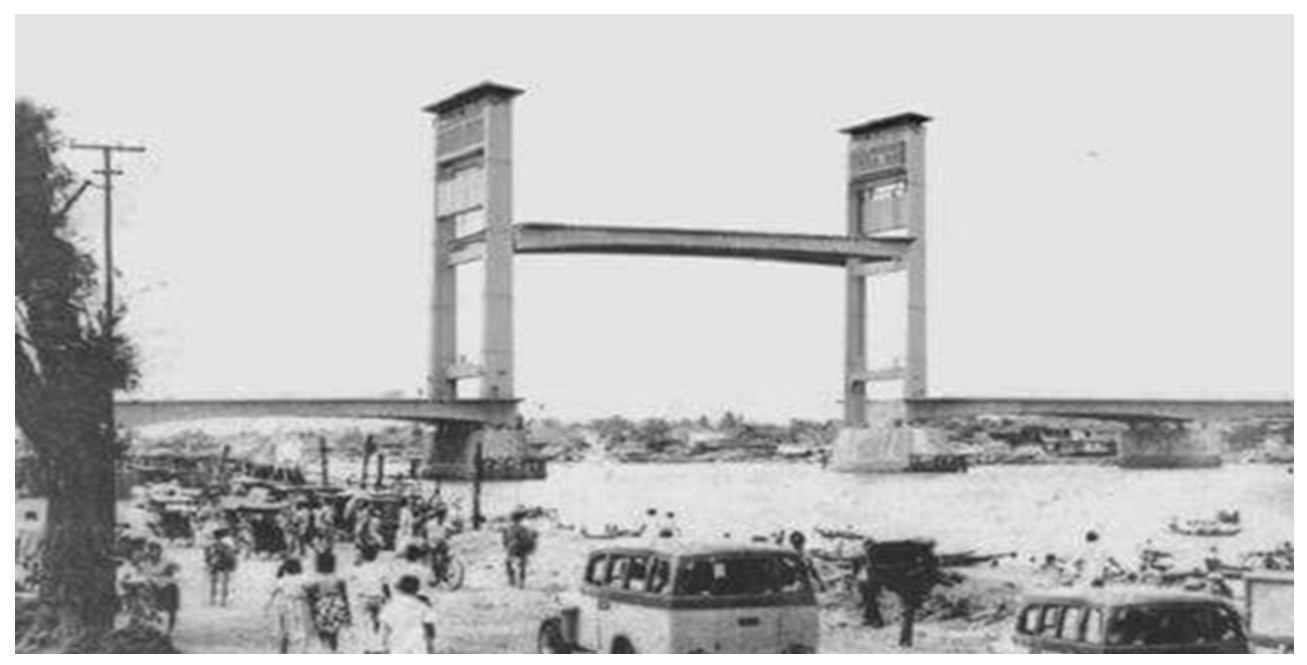

Gambar 1. Jembatan Ampera Tahun 1960

Sumber: httpps://pin.it/26gesOw

HISTORIA: Jurnal Pendidik dan Peneliti Sejarah, p-issn:2620-4789 | e-issn:2615-7993 
HISTORIA: Jurnal Pendidik dan Peneliti Sejarah, 5(1), 65-80. https://doi.org/10.17509/historia.v5i1.36374.

tidak jarang yang masih anak-anak. Mereka menyelam dengan alat yang sederhana yaitu menggunakan kompresor dan selang oksigen, dengan kedalam puluhan meter sampai dasar, dengan waktu penyelaman sampai puluhan menit bahkan sampai $2 / 3$ jam para penyelam rela mempertaruhkan nyawa. Menurut para penyelam, di dasar sungai keadaan gelap dengan jarak pandangnya adalah 0 . Teknik penyelam saat mencari benda-benda ini adalah dengan mengarahkan selang penyedot ke berbagai arah agar tanah dan pasir yang terdapat bendabenda itu naik ke kapal, bahkan tidak jarang mereka meraba bagian dasar dan mengeruk pasir itu. Para penyelam yang memburu benda kuno dan harta karun ini memulai aktivitasnya dari pagi, sore, atau bahkan malam.

Pada gambar tersebut menunjukan anak-anak yang melakukan pencarian harta karun Sungai Musi dan benda peninggalan sejarah. Dimulai dari melakukan penyelaman kemudian mengayak pasir yang telah naik ke kapal untuk melihat apakah ada benda yang diperoleh, dan benda-benda yang diperoleh tersebut dibawa ke tempat barang antik. Selama proses penyelaman dan pencarian ini tidak jarang ketek (perahu) yang digunakan rusak dan perlu di perbaiki. Temuan-temuan tersebut pada akhirnya akan dijual belikan, sehingga dalam hal ini penulis mengambil judul ini supaya kelak benda tersebut masih dapat dilihat dan dibaca meskipun dengan melalui tulisan.

Benda-benda peninggalan sejarah di Sungai Musi yang ditemukan diantaranya terdapat dari berbagai zaman. Temuan benda di Sungai Musi pada masa Kerajaan Sriwijaya yaitu sebagai berikut: Temuan diatas merupakan keramik masa Kerajaan Sriwijaya yang berbentuk guci, keramik tersebut terbuat dari tanah liat yang dibakar dengan suhu tinggi. Benda ini di temukan di dasar Sungai Musi dengan kedalaman kurang lebih 25 meter oleh para penyelam yang mencari benda-benda kuno dengan menggunakan peralatan yang sederhana. Keramik Guci tersebut berukuran lumayan besar, dengan corak garis yang melingkar dan bentuknya oval polos dimana dibagian atasnya terdapat lubang kecil sebagai mulut guci.

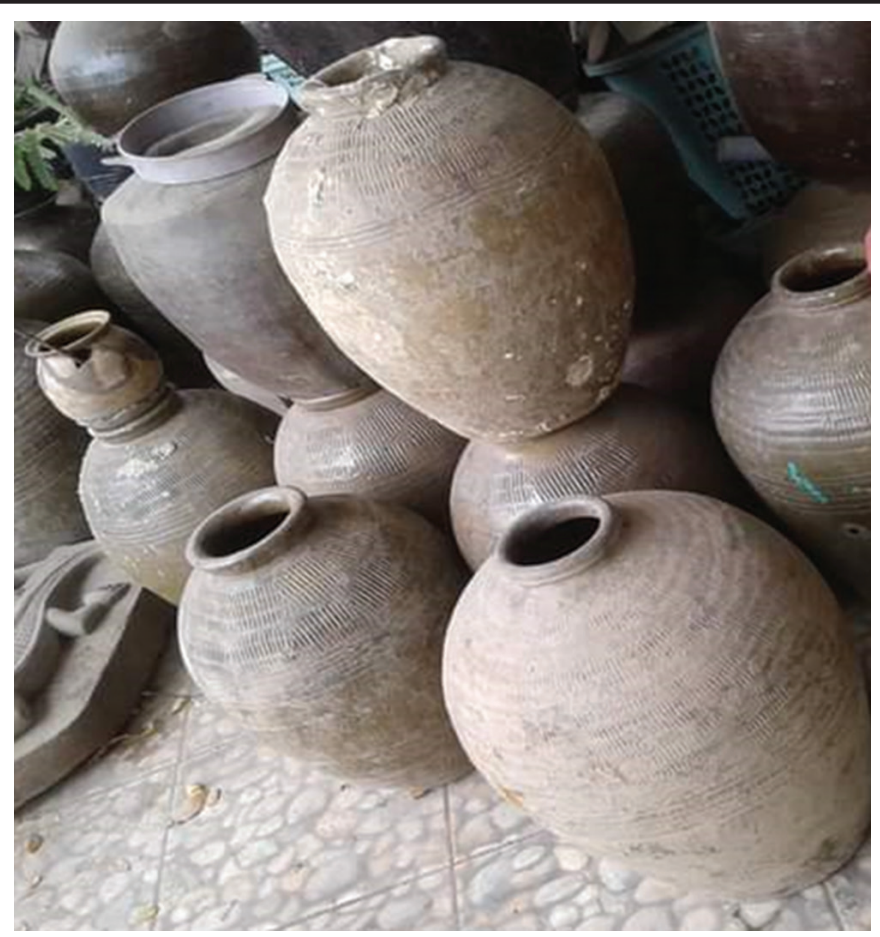

Gambar 2. Keramik berbentuk Guci era Kerajaan Sriwijaya (tanpa skala) Sumber: Dokumentasi Koleksi Kertapati Antik II

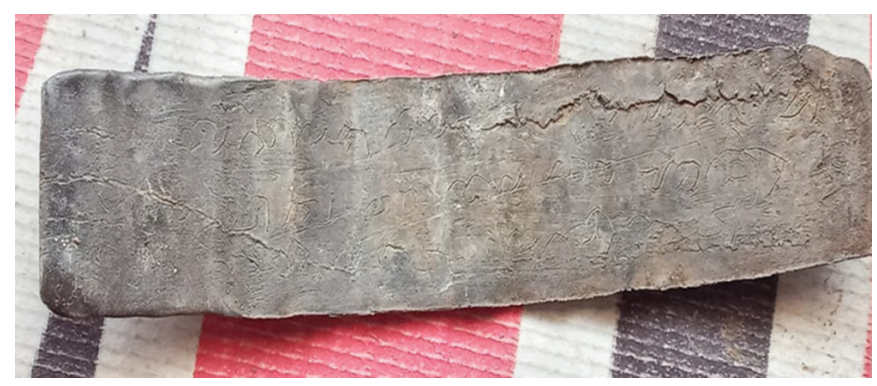

Gambar 3. Surat Timah dari Masa Kerajaan Sriwijaya ditemukan di tepian Sungai Musi (tanpa skala)

Sumber: Dokumentasi Koleksi Kertapati Antik II

Gambar diatas merupakan Surat Timah masa Kerajaan Sriwijaya, benda ini ditemukan di dasar Sungai Musi dengaan kedalaman kurang lebih 25 meter, saat ditemukan surat ini dalam kondisi yang baik, meskipun dengan ada sedikit keretakan, namun masih terlihat tulisan yang ada diatasnya. Surat ini dahulunya dapat digulung adapun bahan dari surat adalah Timah, dengan huruf Palawa dan bahasa Sangsekerta. Isi surat masih belum diketahui. Temuan ini diidentifikasikan sebagai 
peninggalan masa kerajaan Sriwijaya, hal ini dapat di buktikan dengan sudah dikenalnya Timah pada masa Sriwijaya yang berasal dari pulau Bangka.

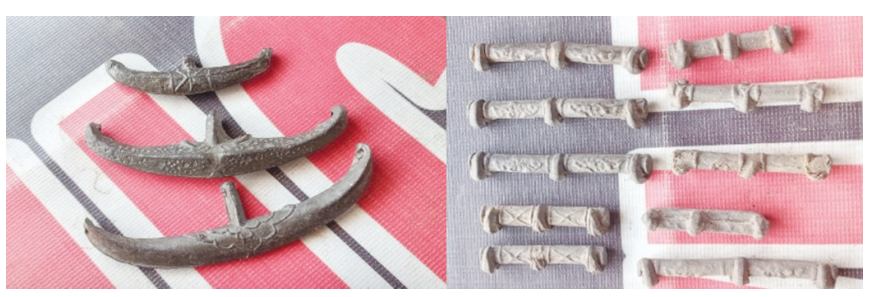

Gambar 4. Alat Barter atau Uang Barang Masa Kerajaan Sriwijaya (tanpa skala)

Sumber: Dokumentasi Koleksi Kertapati Antik II

Temuan diatas merupakan salah satu bentuk mata uang pada masa Kerajaan Sriwijaya yang berbahan dasar dari timah, pada gambar sebelah kiri merupakan Uang Barang Perahu dan yang disebelah kanan adalah Uang Barang Bambu. Sesuai namanya uang barang ini pada masa Kerajaan Sriwijaya digunakan sebagai media berter dan jual beli pada saat transaksi perdagangan. Dikatakan Uang Barang Perahu hal ini di karenakan benda tersebut melengkung berbentuk seperti perahu, dengan sedikit ukiran dan aksen memanjang di tengah. Nilai dari mata uang ini dilihat dari ukurannya, semakin panjang nilainya juga semakin besar, disetiap ukuran sendiri, benda ini memiliki ukiran yang berbeda-beda, yang dapat diibaratkan seperti uang sekarang.

Sedangkan Uang Barang Bambu untuk melihat nilainya dapat dilihat dari ruas dan panjang benda, semakin banyak ruas dan panjang maka nilainya semakin tinggi, adapun temuan benda besarnya seukuran kelingking, dengan panjang 2 ruas jari dan yang paling panjang berukuran kurang lebih sejengkal tangan orang dewasa. Dinamakan Alat Barter Bambu hal ini dikarenakan bentuknya yang beruas dan panjang seperti bambu, disetiap ruasnya terdapat aksen tonjolan setengah lingkaran dengan lubang ditengahnya.

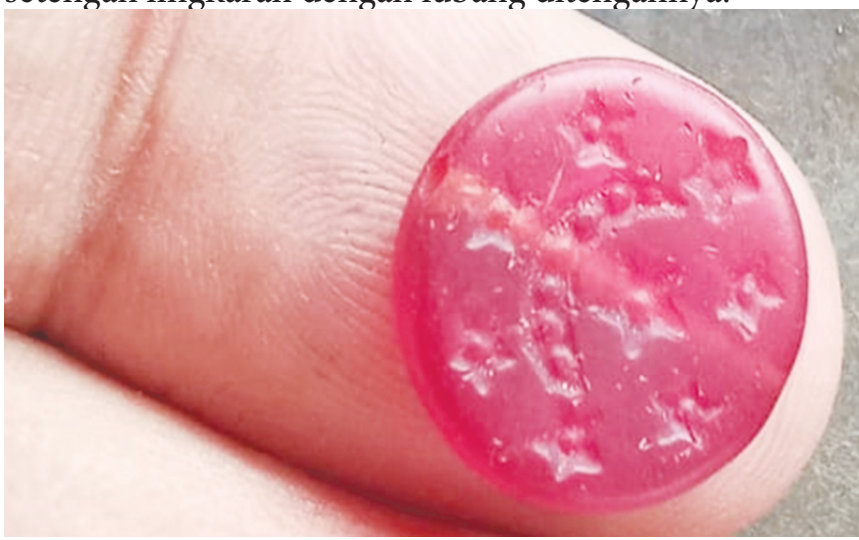

Gambar 5. Batu Gambar Masa Kerajaan Sriwijaya Sumber: Dokumentasi Koleksi Kertapati Antik II
Temuan diatas merupakan Batu Gambar, seperti yang terlihat di Batu Gambar ini terdapat ukiran bulan dan bintang yang memiliki makna tersendiri. Adapun ukuran diameter dari batu gambar ini tidak lebih dari $0,5 \mathrm{~cm}$, dengan warna merah, meskipun demikian warna pada Batu Gambar ini terdiri dari 2 macam yaitu merah dan biru. Dahulunya Batu Gambar ini dijadikan sebagai upeti atau hadiah. Benda ini ditemukan pada dasar Sungai Musi dengan kedalaman kurang lebih 20 meter, yang diambil dengan proses penyedotan.

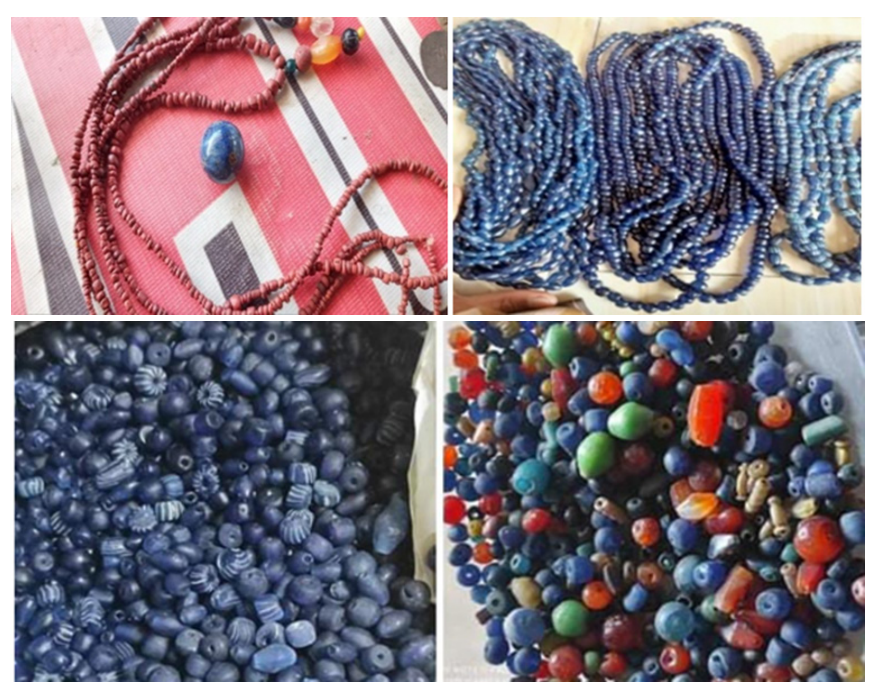

Gambar 6. Manik-Manik Masa Kerajaan Sriwijaya Sumber: Dokumentasi Koleksi Kertapati Antik II

Gambar di atas adalah beragai manik-manik masa Kerajaan Sriwijaya, pada gambar sebelah kiri merupakan manik-manik yang terbuat dari tanah liat dengan proses pembakaran, bentuk dari manik manik ini bulat dengan sedikit lubang kecil ditengahnya, pada gambar manikmanik tersebut telah disusun seperti kalung. Pada tiga gambar sebelah kanan merupakan manik manik yang terbuat dari kaca, ditemukan berbagai bentuk dan ukuran serta warna yang berbeda, warna-warna manik yang ditemukan diantaranya biru polos, orange, hijau, merah, dan perpaduan biru dengan putih. Bendabenda ini ditemukan di dasar Sungai Musi dengan kedalaman kurang lebih 20 meter, yang ditemukan oleh para penyelam Sungai Musi, yang diambil dengan cara penyedotan.

Manik-manik dengan ukuran kecil dan sederhana digunakan oleh rakyat biasa, dan yang besar untuk para penguasa. Pada masa Kerajaan Sriwijaya manik-manik ini digunakan sebaagai perhiasan, seperti dijadikan kalung ataupun gelang. Temuan manik-manik dengan bahan kaca ini menunjukan benda ini masih muda karena telah ditemukan pengolahan benda dari kaca daripada yang sebelumnya yang terbuat dari tanah liat. 
HISTORIA: Jurnal Pendidik dan Peneliti Sejarah, 5(1), 65-80. https://doi.org/10.17509/historia.v5i1.36374.

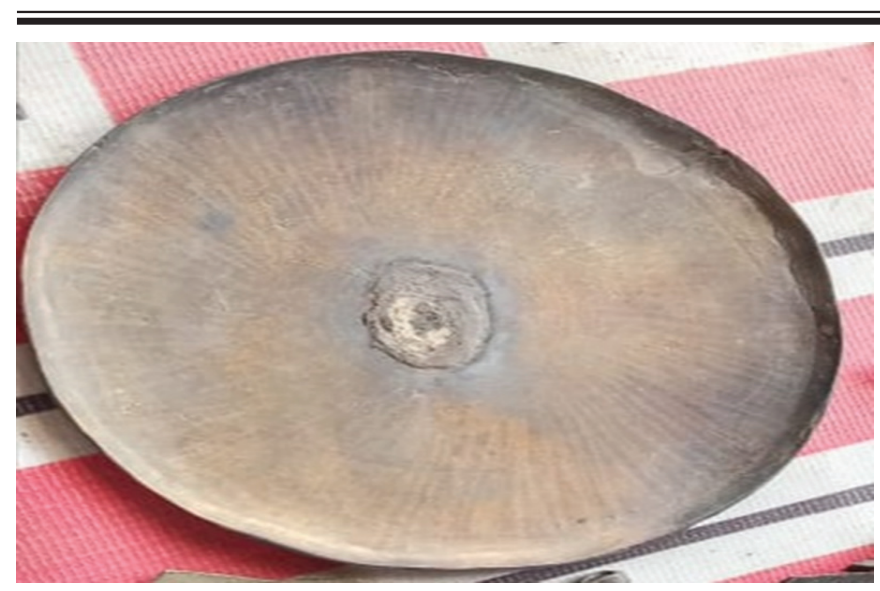

Gambar 7. Cermin Perunggu (tanpa skala) Sumber: Dokumentasi Koleksi Kertapati Antik II

Gambar diatas adalah cermin masa Kerajaan Sriwijaya. Benda ini ditemukan di Saungai Musi dengan kedalaman kurang lebih 20 meter oleh penyelam. Cermin berbentuk bulat seperti lempengan, dengan tambahan aksen tinggi yang melengkung melingkar di tepinya, saat ditemukan benda ini memiliki lingkaran kecil yang sedikit berekstur ditengahnya seperti gambar.

Berbeda dengan cermin sekarang yang terbuat dari kaca, cermin tersebut terbuat dari perunggu. Meskipun dalam foto tidak terlihat seperti cermin, namun sebenarnya cermin perunggu ini dapat memantulkan gambar seperti cermin kaca sekarang. Karena benda ini terbuat dari perunggu maka dapat memantulkan gambar meskipun hasil bayangan yang dipantulkan tidak sejernih yang sekarang.

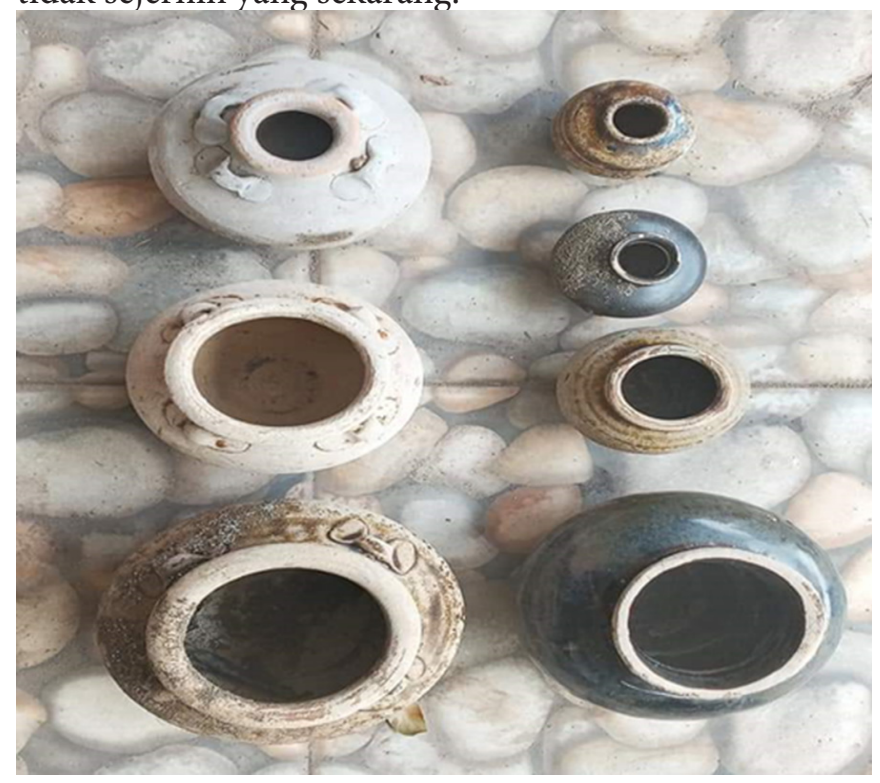

Gambar 8: Gerabah Masa Kerajaan Sriwijaya (tanpa skala)

Sumber: Dokumentasi Koleksi Kertapati Antik II

Gambar temuan diatas merupakan Gerabah, yaitu salah satu benda peninggalan Kerajaan Sriwijaya yang banyak ditemukan, fungsi gerabah pada masa Kerajaan Sriwijaya digunakan untuk kegiatan sehari-hari seperti digunakan sebagai wadah. Pada sisi sebelah kiri gambar gerabah memiliki bentuk oval dengan empat ornamen seperti kuping di leher gerabah dan di bagian bawah gerabah terdapat kaki tinggi yang melingkar, temuan ini memiliki berberapa warna, pada gambar bagian paling bawah berwarna cokelat gelap, tengah berwarna putih dan paling atas berwarna keabu-abuan.

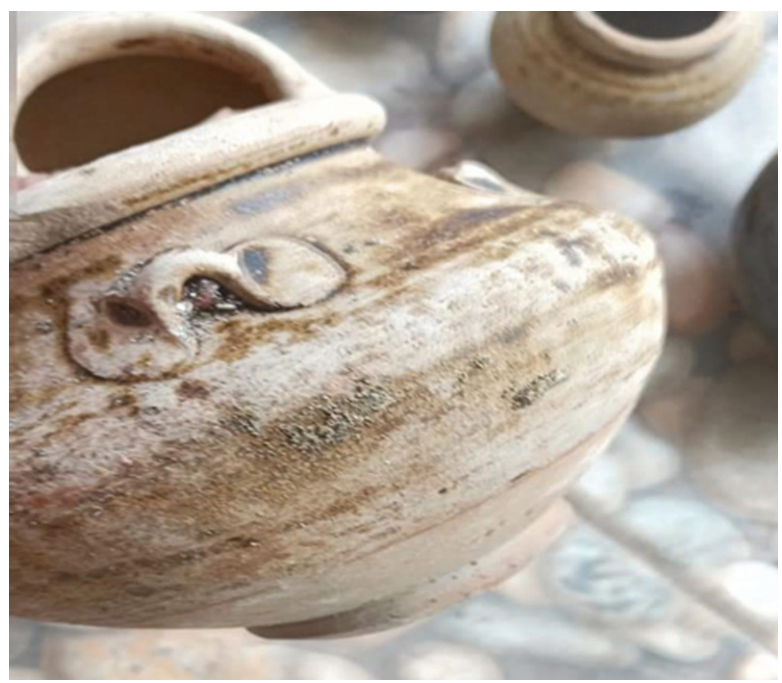

Gambar 9: Detail Bentuk Ornamen Kuping Pada

Gerabah Gambar Sebelah Kiri

Sumber: Dokumentasi Koleksi Kertapati Antik II

Benda ini di temukan di Sungai Musi di kedalaman kurang lebih 20 meter dengan keadaan utuh tanpa ada keruskan oleh para penyelam pemburu harta karun Sungai Musi. Sedangkan pada sebelah kanan gambar itu merupakan keramik. Gerabah terbuat dari tanah liat, dimana proses pembuatannya dilakukan secara manual dengan proses pembakaran. Gerabah yang ditemukan di Sungai Musi ada dari berbagai bentuk dan ukuran.

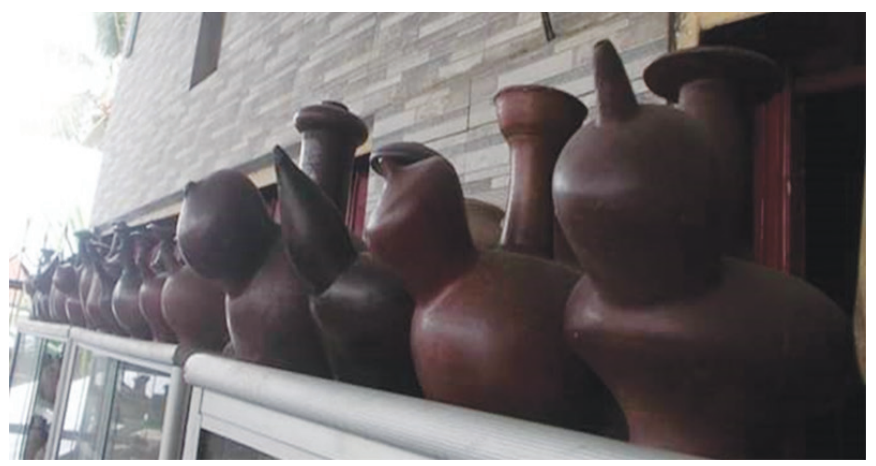

Gambar 10: Kendi Tarakota Era Sriwijaya

Sumber: Dokumentasi Koleksi Kertapati Antik II

Gambar diatas merupakan Kendi Tarakota yang ditemukan di dasar Sungai Musi, benda ini masih dalam

HISTORIA: Jurnal Pendidik dan Peneliti Sejarah, p-issn:2620-4789 | e-issn:2615-7993 
kondisi bagus saat ditemukan. Adapun bentuk kendi menyerupai teko air, dibagian corong untuk minumnya ada yang berbentuk bulat dan ada juga yang oval dengan ujung melancip, corong minum dibuat sedemikian rupa dengan gambaran itu merupakan bagian dada wanita. Kendi yang ditemukan tersebut berjenis Kendi Susu. Sehingga pada masa itu saat meminum dari kendi diibaratkan minum dari dada wanita. Pada bagian leher kendi memanjang dan terdapat mulut di bagian atas, dari banyaknya yang ditemukan variasi bagian leher kendi memiliki panjang yang berbeda, ada yang panjang dan ada juga yang dibuat pendek, dan pada bagian mulutnya juga memiliki bentuk berbeda, namun yang banyak ditemukan adalah model bulat dengan sedikit tambahan aksen seperti gelombang ataupun cekungan. Kendi tersebut terbuat dari tanah liat dengan proses pembakaran. Pada masa Kerajaan Sriwijaya Kendi ini digunakan sebagai tempat air minum.

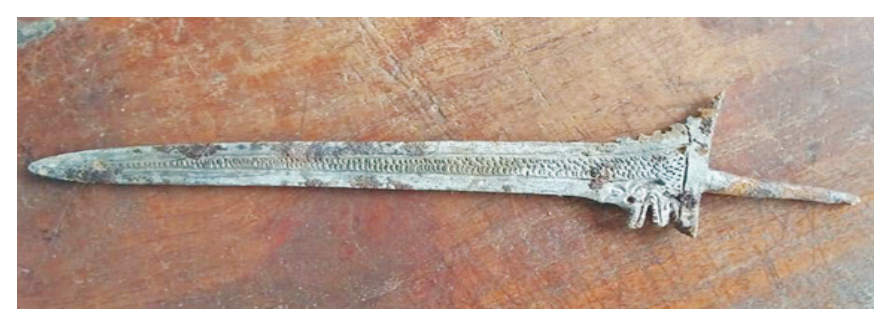

Gambar 11: Pedang Naga Sriwijaya (tanpa skala) Sumber: dokumentasi Kertapati Antik II

Gambar tersebut merupakan Pedang Naga Sriwijaya, benda ini ditemukan di Sungai Musi dengan keadaan cukup baik namun sedikit berkarat, pada bagian pegangan pedang hancur, yang mana diperkirakan bagian pegangan itu berbahan dasar kayu, sehingga hancur saat berada di dasar air selama puluhan tahun. Pedang ini berbahan dasar timah yang dileburkan, dimana yang mana pada masa itu sudah mengenal peleburan timah. Pada bagian pangkal sebelah sisi pedang berbentuk seperti naga dengan mulut terbuka yang memperlihatkan giginya, serta memiliki lubang seperti mata, pada sisi lainnya bergerigi dengan lebih panjang ujung sisinya. Untuk bagian tengah pedang memiliki ukiran seperti sisik, yang digambarkan itu merupakan sisik naga. Pedang ini digunakan sebagai senjata.

\section{b. Benda-Benda Peninggalan Masa Kesultanan}

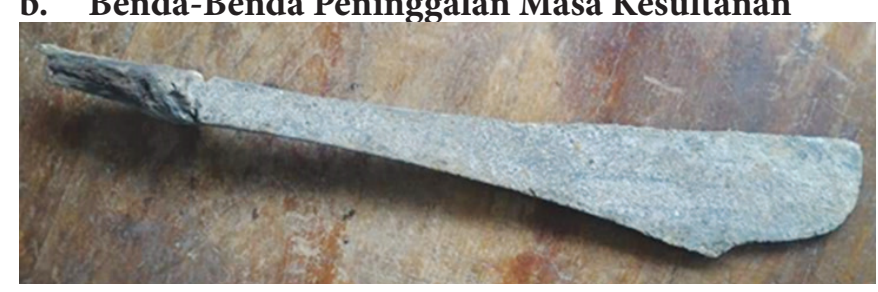

Gambar 12 Golok

Sumber: dokumentasi Kertapati Antik II
Gambar diatas merupakan temuan golok masa Kesultanan Palembang, yang ditemukan di dasar Sungai Musi dengan kedalaman kurang lebih 20 meter oleh penyelam pemburu harta karun Sungai Musi. Benda ini ditemukan pada tahun 2019 dengan keadaan baik, namun pada bagian pegangan golok mengalami kerusakan, hal ini dikarenakan terlalu lama berada di dalam sungai sedangkan bahannya terbuat dari kayu. Benda ini berbentuk memanjang dan melebar pada ujungnya. Adapun ukurannya kurang lebih setengah meter. Pada era Kesultanan, benda ini digunakan sebagai senjata.

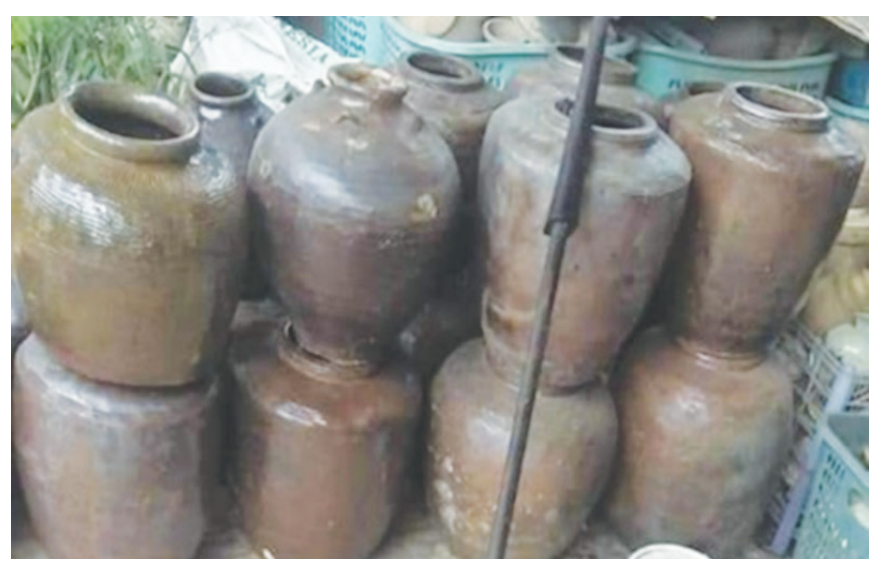

Gambar 13. Keramik berbentuk Guci Era Kesultanan Sumber: dokumentasi Kertapati Antik II

Gambar tersebut merupakan Guci masa Kesultanan Palembang, Guci ini ditemukan di tepian Sungai Musi. Guci tersebut terbuat dari tanah liat dengan proses pembakaran yang tinggi sehingga guci ini memiliki kualitas yang baik. Benda tersebut ditemukan sejak 2019, saat ditemukan kondisi guci dalam keadaan baik dan masih utuh. Ukuran dari benda ini juga cukup besar. Adapun guci ini berbentuk oval dimana dibagian atas lebih besar, guci ini memiliki leher yang pendek dan mulut diatasnya dengan bentuk melingkar polos tanpa ada aksen apapun. Karena terbuat dari tanah dan tidak ada campuran lainya, guci tersebut berwarna coklat.

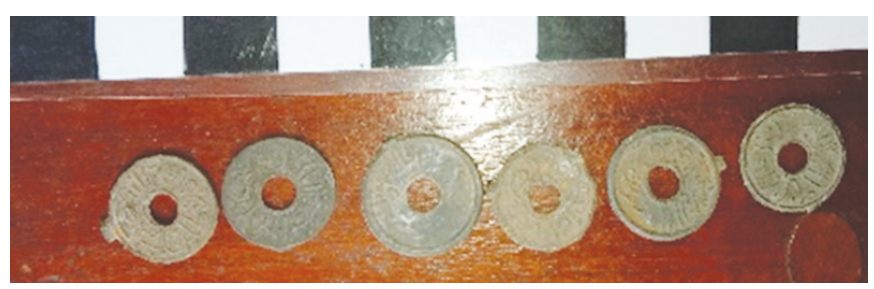

Gambar 14. Mata Uang Koin Era Kesultanan Sumber: Dokumentasi Pribadi

Gambar diatas merupakan mata uang yang berbentuk koin pada era Kesultanan Palembang, ditemukan di dasar Sungai Musi oleh penyelam pencari harta karun Sungai Musi. Benda ini terbuat dari logam, dengan bentuk bulat dan ada lubang yang kecil pada

HISTORIA: Jurnal Pendidik dan Peneliti Sejarah, p-issn:2620-4789 | e-issn:2615-7993 
HISTORIA: Jurnal Pendidik dan Peneliti Sejarah, 5(1), 65-80. https://doi.org/10.17509/historia.v5i1.36374.

tengahnya. Pada bagian sisi depan dan belakangnya nya terdapat tulisan-tulisan Arab yang mencirikhaskan masa kesultanan yang bercorak Islam. Koin tersebut pada masa Kesultanan digunakan sebagai mata uang dan alat perdagangan barang.

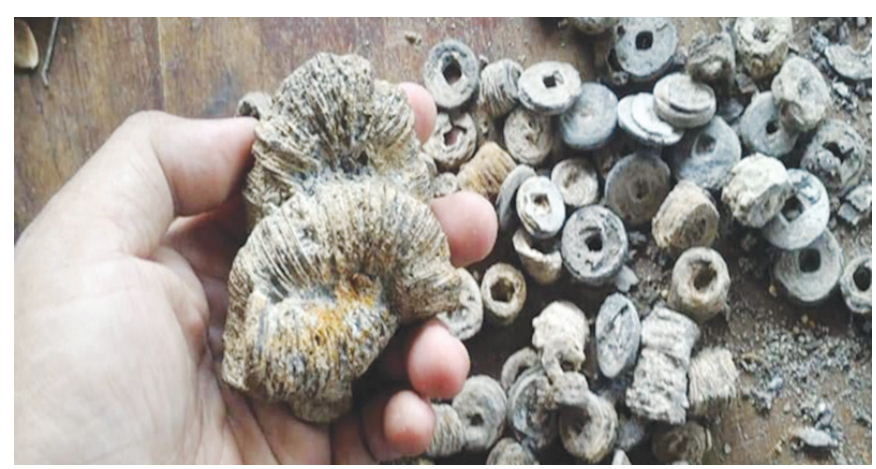

Gambar 15. Mata Uang Koin yang Sudah Menyatu Sumber: Dokumentasi Kertapai Antik II

Karena terlalu lama berada di dalam air, koin tersebut sudah menggumpal dan menyatu dengan koin lainnya. Namun banyak juga temuan koin yang masih dalam keadaan baik. Dengan ditemukannya mata uang koin masa Kesultanan menunjukan adanya kegiatan ekonomi yang maju, dimana pada masa kerajaan Sriwijaya masih mengenal uang barter, pada masa Kesultanan sudah dikenal nilai dari mata uang.

\section{c. Benda-Benda Peninggalan Masa Kolonial}

Masa kolonial merupakan masa dimana masuknya orang-orang barat ke Nusantara, dalam catatan sejarah bangsa kolonial juga masuk ke kota Palembang. Setelah Kesultanan Palembang dihapuskan oleh pemerintahan Kolonial Belanda, Palembang berubah menjadi ibu kota Keresidenan Palembang. Selama tahun-tahun keberadaannya, maka banyak temuan benda peninggalan yang dapat dijadikan sebagai sumber belajar. Bendabenda masa kolonial yang ditemukan di Sungai Musi diantaranya yaitu:

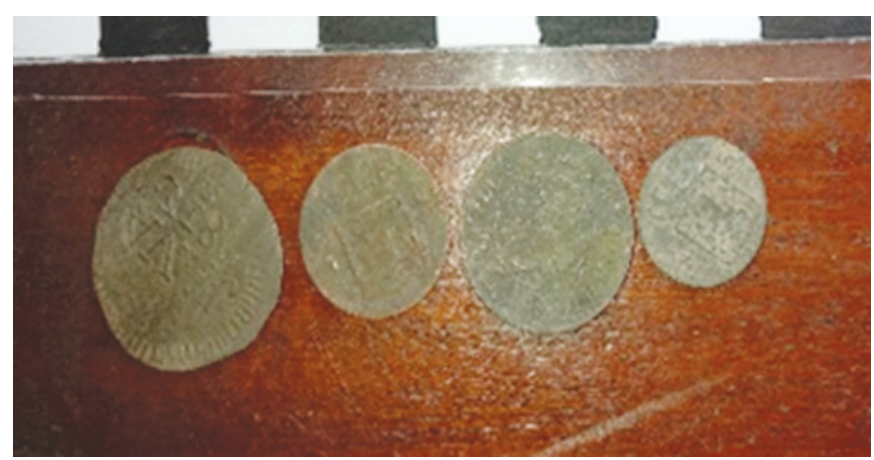

Gambar 16. Koin VOC Sumber: Dokumentasi Pribadi

Gambar diatas merupakan mata uang koin VOC, digunakan sebagai mata uang saat melakukan transaksi dan perdagangan. Koin yang ditemukan berbentuk bulat dengan bahan dasar logam. Saat ditemukan koin ini dalam kondisi baik dan utuh tanpa ada kerusakan. Pada bagian sisi depan dan belakang koin terdapat aksen tulisan dan nilai dari mata uang koin tersebut.

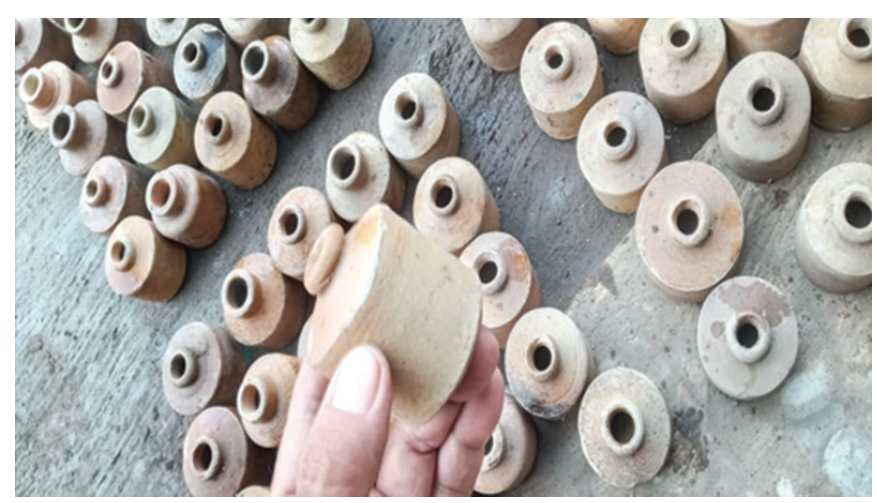

Gambar 17. Wadah Tinta

Sumber: Dokumentasi Koleksi Kertapati Antik II

Wadah tinta merupakan benda peninggalan masa Kolonial, sesuai namanya benda tersebut digunakan sebagai wadah penampung cairan tinta. Bahan dasar dari benda ini adalah tanah liat yang dibakar dengan suhu sangat tinggi, sehingga memiliki stuktur yang keras dan berkualitas baik. Seperti pada wadah tinta pada umumnya benda ini berbentuk seperti tabung dengan lubang diatasnya, dengan ukuran yang bervariasi.
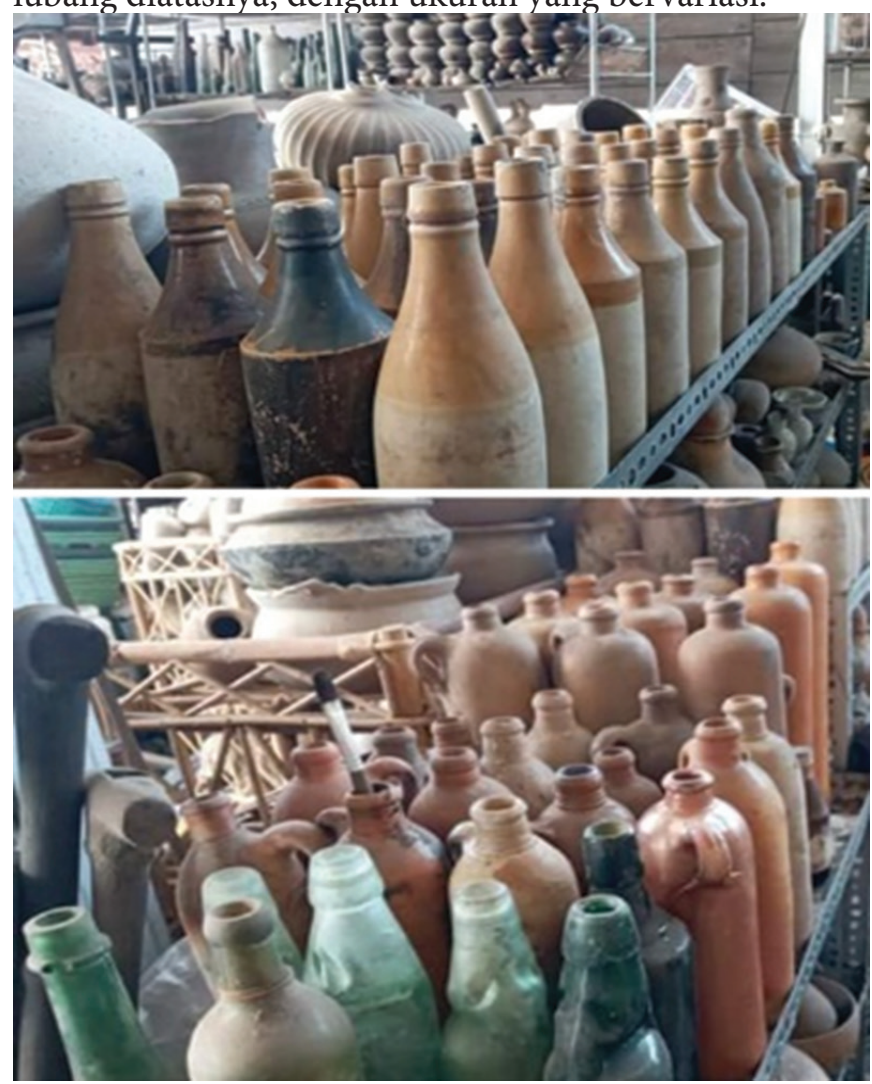

Gambar 18. Botol Jamu dan Botol Alkhohol Sumber: Dokumentasi Koleksi Kertapati Antik II

HISTORIA: Jurnal Pendidik dan Peneliti Sejarah, p-issn:2620-4789 | e-issn:2615-7993 
Gambar diatas merupakan botol jamu dan botol alkhohol masa Kolinial. Pada gambar bagian atas merupakan botol jamu yang digunakan sebagai wadah obat-obatan herbal. Adapun benda ini memiliki bentuk yang hampir sama dengan pin dalam permainan Bowling dan pada bagian atas terdapat tutupnya. Gambar selanjutnya yang di bagian bawah merupakan botol alkhohol pada masa Kolonial, benda ini memiliki bentuk seperti tabung yang memanjang, adapun ukuran dari botol tersebut ber-kapasitas setengah liter dan 1 liter air. Kedua benda tersebut terbuat dari tanah liat yang dibakar dalam suhu yang sangat tinggi, sehingga memiliki ketahanan yang kuat dengan tekstur keras. Setiap bendabenda tersebut memiliki aksen tulisan yang menunjukan merek pada setiap minuman serta nama-nama kota yang ada di Belanda seperti Netherland, Amsterdam dll. Adapun merek-merek minuman alkhohol pada masa Kolonial ini seperti Java Bier, Ankerpils, dan Heinekens.

Pada awalnya, bier dan minuman alkhohol hanya dikenal oleh orang-orang yang bekerja pada pemerintahan kolonial sebagai serdadu, pelaut atau bahkan pegawai negeri, namun lama-lama kebiasaan para pegawai pemerintah kolonial tersebut diikuti oleh masyarakat Indonesia. Kebiasaan minum orang-orang kolonial ini menganggap bahwa alkhohol merupakan minuman kuat. Sehingga minum alkhohol sudah menjadi kebiasaan, akibatnya banyak industri minuman keras.

\section{Nilai-nilai Sejarah dan Budaya Benda Peninggalan Kuno di Sungai Musi}

Setiap benda-benda peninggalan sejarah yang ditemukan memiliki nilai. Nilai sendiri merupakan kualitas atau suatu hal yang dianggap penting, menurut beberapa ahli diantaranya Sidi Gazalba, dapat dikatakan bahwa nilai adalah suatu hal yang abstrak, dan ideal, yang menjadikan perbedaan antara batu dengan emas. Nilai juga berhubungan antara subjek penelitian dan objek penelitian, yang mana hal ini sama dengan bendabenda peninggalan sejarah yang ditemukan di Sungai Musi yang memiliki nilainya masing-masing. Nilainilai yang terdapat di peninggalan sejarah Saungai Musi tersebut yaitu:

\section{a. Nilai Politik dan Kekuasaan}

Politik dan kekuasaan merupakan suatu usaha atau kegiatan yang berkaitan dengan penyelenggaraan pemerintahan ataupun negara. Nilai politik dan kekuasaan menunjukan seberapa baik atau buruknya sistem politik serta hebatnya kekuasaan masa lampau. Dalam hal ini termasuk hubungan diplomasi dan hubungan lain dengan negara lain yang menunjukan adanya keberadaan suatu negara. Pada masa Kerajaan Sriwijaya, terdapat hubungan diplomasi multirateral dengan negara China pada masa Dinasti Tang. Hubungan yang terjadi antara Kerajaan Sriwijaya dan Dinasti Tang bermula ketika kedua kerajaan saling mengirimkan hadiah dan upeti. Dalam kitab Xin Tang Shu yang merupakan kitab sejarah baru Dinasti Tang menyatakan bahwa Kerajaan Sriwijaya mengirimkan utusan ke Dinasti Tang pada tahun 670-673 M, yang kemudian dibalas oleh Dinasti Tang dengan mengirimkan utusan dari kekaisaran pada $683 \mathrm{M}$, hal ini merupakan awal dimulainya hubungan tersebut. Hubungan antara kedua kerajaan ini terus berlanjut dengan saling mengirimkan utusan, yaitu pada tahun 702,716 , dan $724 \mathrm{M}$ atas nama Shih-lit'o-lo-pa-mo (Sri Indrawarman), kemudian pada tahun 728dan $742 \mathrm{M}$ atas nama Raja Liu-t'eng-wei-kung (Rudrawikrama), pada tahun setelahnya yaitu pada 742 $M$ hingga 904 pengiriman utusan tidak disebut lagi (Saputra \& Hasan, 2014, pp. 64-65).

Selain berhubungan dengan Dinasti Tang, Kerajaan Sriwijaya juga melakukan hubungan diplomasi dengan berbagai Dinasti China seperti Ming, Qing, dan Song, masih dengan cara yang sama, kerajaan-kerajaan ini saling mengirimkan utusan dengan membawa hadiah dan upeti. Dan pada masa Dinasti Song utusan Kerajaan Sriwijaya ke China semakin banyak. Hadiah dan upeti yang dikirimkan berupa kain sutera, perhiasan dan porselen-porselen yang indah. Hubungan antara kerajaan Sriwijaya dengan Dinasti masa Cina dapat dibuktikan dari berbagai keramik porselen yang ditemukan di Sungai Musi. Dengan adanya hal ini telah menunjukan eksistensi dan keberadaan Kerajaan Sriwijaya, dimana Kerajaan Sriwijaya telah berkuasa jauh dan kuat hingga telah melakukan hubungan kerjasama dengan berbagai Dinasti di Cina.

Setelah Kerajaan Sriwijaya runtuh oleh serangan dari Kerajaan Cola, akhirnya pada abad ke 17 ke 18 adalah kekuasaan Kesultanan Palembang, dimana sebelumnya wilayah Palembang ini menjadi Kerajaan Palembang pada masa Demang Lebar Daun dan Sapurba, kemudian menjadi wilayah taklukan Singasari, Majapahit, dan Demak Islam. Setelah masa Ki Mas Hindi akhirnya Palembang dapat lepas dari Mataram dan Berdirilah Kesultanan Palembang Darussalam. Masa Kesultanan bercorak Islam, yang mana dalam hal ini dapat dilihat dari berbagai temuan-temuanya yang bertuliskan huruf Arab, seperti koin-koin perdagangan yang ditemukan di Sungai Musi, pada bagian sisinya terdapat tulisantulisan Arab. Kesultanan Palembang juga memiliki hubungan kerjasama perdagangan, dimana dalam hal ini menerapkan sistem politik laut. Pada masa Sultan 
HISTORIA: Jurnal Pendidik dan Peneliti Sejarah, 5(1), 65-80. https://doi.org/10.17509/historia.v5i1.36374.

Muhammad Mansyur politik yang digunakan adalah menyelesaikan masalah dengan keris dan peluru, adapun hal ini dapat dilihat dari temuan-temuan senjata seperti keris, dan golok yang ditemukan di Sungai Musi. Kesultanan Palembang juga melakukan hubungan diplomasi dengan pihak Kolonial perihal perdagangan yang saling menguntungkan.

\section{b. Nilai perjuangan dan Kekuatan}

Kerajaan Sriwijaya merupakan kerajaan yang besar, dengan daerah kekuasaannya yang luas. Sebagai kerajaan yang besar Sriwijaya tentunya memiliki pertahanan dan kekuatan yang baik dalam mempertahankan daerah kekuasaannya. Nilai perjuangan dalam hal ini berkaitan deengan usaha yang dilakukan agar kerajaan selalu berkembang kearah kemajuan dan mempertahankan kedudukan. Pedang yang ditemukan di Sungai Musi merupakan senjata yang digunakan pada masa kerajaan Sriwijaya yang memiliki nilai perjuangan dan kekuatan, dimana untuk menangani oknum yang membangkang dan serangan dari luar, senjata inilah yang digunakan.

Pada masa Kesultanan Palembang, nilai perjuangan dan kekuatan dapat dilihat dari berbagai temuan keris dan golok. Dimana pada masa itu untuk mempertahankan dan mengurus pihak yang melawan kesultanan oleh Sultan Muhammad Mansyur diselesaikan dengan cara kekerasan. Meskipun temuan keris dan golok yang ditemukan di sungai Musi belum diketahui dahulunya dimiliki oleh siapa, namun dari adanya benda tersebut menunjukan dahulunya terdapat perjuangan dan kekuatan yang dimiliki kesultanan untuk tetap mempertahankan kedudukannya.

\section{c. Nilai Ekonomi dan Teknologi}

Ekonomi merupakan kegiatan atau usaha manusia untuk memenuhi kebutuhan hidup. Adanya temuan berupa uang barter perahu dan bambu, serta koin-koin dari masa kesultanan dan kolonial menunjukan adanya aktivitas ekonomi berupa jual beli dan perdagangan, dimana benda itu sebagai media pembayaran. Pada masa Kerajaan Sriwijaya pedagangan telah berkembang sangat pesat, sebagai kerajaan maritim Sriwijaya memanfaatkan perairanya sebagai jalur pelayaran dan perdagangan. Selat Malaka merupakan pintu masuk bagi para pedagang India, China untuk masuk ke Nusantara (Sholeh, Sari, \& Berliani, 2019), sehingga merupakan daerah yang strategis bagi Kerajaan Sriwijaya, dengan menguasai wilayah tersebut telah memberikan dampak ekonomi yang besar bagi Sriwijaya, hal ini dilihat dari semakin ramainya kapal-kapal pedagang yang singgah. Kerajaan Sriwijaya tidak hanya berhubungan dagang dengan negeri-negeri Cina, melainkan juga dengan bangsa Arab seperti pada masa Dinasti Umayah. Selain koin, guciguci besar yang ditemukan dahulunya digunakan sebagai wadah untuk barang-barang dagangan, dan wadah air yang digunakan sebagai bekal dalam perjalanan.

Pada masa Kesultanan dan Kolonial perdagangan yang memanfaatkan Sungai Musi juga masih berjalan, seperti pada masa Kesultanan perdagangan berkembang baik, dengan hasil dari pertanian seperti lada yang dahulunya sangat diminati oleh bangsa Eropa, yang mana pada awal abad XV kebutuhan Eropa mengenai lada miningkat tiga kali lipat, yang membuat tanaman ini berkembang pesat di wilayah Nusantara. Untuk pulau Sumatera sendiri, wilayah penghasil lada terbanyak adalah Pidi, Pasai, Indragiri, Kampar, Pariaman, Indrapura, Silebar, Jambi, Palembang, dan Lampung. Pada sekitar tahun-tahun tersebut Kesultanan Palembang telah memiliki hubungan kontrak dengan VOC yang diwajibkan untuk memberikan hasil pertaniannya, sehingga saat harga lada naik empat kali lipat, penguasa Palembang mewajibkan rakyatnya untuk menanam lada, yaitu diwilayah uluan (Rawas), Bangka, dan Lampung. Selain lada, perdagangan masa Kesultanan juga berkembang di pengolahan Timah yang berada di pulau Bangka, dengan sumber daya yang melimpah ini, mengakibatkan bangsa Eropa semakin tertarik dengan Palembang. Koin-koin masa Kesultanan dan koin VOC serta guci-guci yang ditemukan telah menunjukan adanya perdagangan tersebut.

Dengan ditemukannya koin-koin dan alat perdagangan di sekitar Sungai Musi selain menunjukan aktivitas ekonomi, tetapi juga menunjukan telah berkembangnya teknologi bidang perdagangan, karena telah mengenal nilai tukar dan cara yang efektif untuk melakukan transaksi yang saling menguntungkan, tanpa ada berat sebelah. Timah dan logam yang digunakan sebagai mata uang ini menunjukan majunya peradaban dahulu yang telah memahami pengolahan.

\section{d. Nilai Estetika}

Nilai Estetika merupakan nilai keidahan. Nilai estetika dapat dilihat dari berbagai jenisnya yaitu bentuk, warna, tema dan motif hias. Dari segi jenis bentuk, karya seni dipengaruhi oleh bentuk objek yang memiliki daya tarik utama suatu karya seni, jenis bentuk dibedakan menjadi dua, yaitu dua dimensi seperti lukisan, hiasan dinding, foto dll, dan tiga dimensi seperti patung, guci, keramik, dll yang memiliki volume, ruang dan kedalaman. Selanjutnya warna, jenis nilai estetika warna mengandung unsur yang dipengaruhi warna-warna dari suatu objek itu sendiri. Jenis nilai estetika berdasarkan tema berarti keindahan dari sebuah karya seni dilihat dari gagasan yang ingin disampaikan oleh pembuat, 
seperti tema nilai budaya, alam, dll. Selanjutnya jenis nilai estetika berdasarkan motif hias, yaitu bentuk ukiran atau pola-pola, gambar yang dimiliki oleh sebuah objek benda.

Setiap benda-benda yang ditemukan di Sungai Musi memiliki nilai estetikanya masing-masing, seperti setiap ukiran dan pola yang terdapat pada batu gambar dengan ukiran bintang dan bulan dengan maknanya tersendiri, warna pada manik-manik yang digunakan sebagai perhiasan, memiliki kesan keindahan, bentuk dari setiap benda-benda memiliki nilai dan maknanya misalnya kendi tarakota.

\section{Respon dan Penerapan Benda-Benda Peninggalan Sejarah di Sungai Musi di SMK Negeri 2 Palembang}

Benda-benda peninggalan sejarah yang ditemukan di Sungai Musi berkaitan dengan masa Kerajaan Hindu Budha, Kesultanan Palembang Darussalam dan Kolonialisme di Palembang. Setelah melakukan wawancara dengan ibu RF selaku guru mata pelajaran sejarah di SMK Negeri 2 Palembang materi mengenai benda-benda peninggalan sejarah di Sungai Musi Palembang sesuai dengan Kompetesi Dasar (KD) dan Indikator Pencapainan Kopetensi (IPK) yang terdapat dalam silabus kalas $\mathrm{X}$ sesuai kurikulum k-13. Setelah ditentukan materi mengenai benda-benda peninggalan sejarah di Sungai Musi termasuk dalam materi sejarah kelas $\mathrm{X}$ tingkat SMA/SMK yang telah sesuai dengan silabus kurikulum k-13 termasuk dalam KD (Kompetesi Dasar).

Kompetensi Dasar 3.3. Menganalisis berbagai teori tentang proses masuknya agama dan kebudayaan Hindu dan Budha serta pengaruhnya terhadap kehidupan masyarakat Indonesia (pemerintahan, budaya). Indikator Pencapaian Kompetesi (IPK) 3.4.1 menjelaskan temuan benda-benda peninggalan sejarah di Sungai Musi masa Kerajaan Sriwijaya.

Kompetesi Dasar (KD) 3.4 Menganalisis berbagai teori tentang proses masuknya agama dan kebudayaan Islam serta pengaruhnya terhadap kehidupan masyarakat Indonesia (ekonomi, pemerintahan, budaya). Indikator Pencapaian Kompetesi (IPK) 3.5.1 menjelaskan temuan benda-benda peninggalan sejarah di Sungai Musi pada masa Kesultanan Palembang Darussalam.

Kompetesi Dasar (KD) 3.5 Menganalisi proses masuk dan perkembangan penjajahan bangsa Eropa (Portugis, Spanyol, Belanda, Inggris) ke Indonesia. Indikator Pencapaian Kompetesi (IPK) 3.6.1 menjelaskan mengenai benda-benda peninggalan sejarah di Sungai Musi pada masa Kolonialisme.
Jadi materi benda-benda peninggalan sejarah di Sungai Musi dapat dijadikan materi pembelajaran kelas $\mathrm{X}$ di SMK Negeri 2 Palembang. Selain itu materi ini dapat dikembangkan lagi supaya siswa dapat memahami masa kerajaan Hindu-Budha khusunya kerajaan Sriwijaya, masa Islam, yaitu Kesultanan Palembang Darussalam, dan masa kolonialisme di Palembang. Adapun respon siswa terhadap materi yang di berikan cukup jelas dan sesuai dengan pembelajan, sebagian besar sisiwa mengatakan bahwa materi tersebut sangat membantu memudahkan dalam proses belajar sehingga mudah untuk memahami materi pelajaran. Materi mengenai benda-benda peninggalan sejarah di Sungai Musi dapat di ajarkan kepada peserta didik untuk menambahkan pengetahuan dan wujud nyata keberadaan kerajaan Sriwijaya, Kesultanan dan Kolonial melalui bukti yang sudah dituliskan. Selain itu materi ini diharapkan dapat menambah motivas belajar sisiwa, dan menambahkan kecintaannya terhadap tanah air.

\section{SIMPULAN}

Berdasarkan hasil penelitian dan pembahasan yang telah penulis sampaikan mengenai benda-benda peninggalan sejarah di Sungai Musi sebagai Sumber Pembelajaran Sejarah dapat disimpulkan bahwa temuan benda-benda di Sungai Musi sangat banyak, namun sayangnya benda-benda tersebut sebagian telah dijual belikan, adapun temuan-temuan tersebut berasal dari berbagai masa, mulai masa Kerajaan Sriwijaya, Kesultanan Palembang Darussalam, dan Kolonialisme di Palembang.

Sungai Musi dahulunya juga memiliki peran yang besar, dimana pada masa kerajaan Sriwijaya hingga kolonial digunakan sebagai jalur perdagangan dan pelayaran, yang secara tidak langsung membawa agama Budha dan Islam masuk ke Palembang. Selain itu Sungai Musi juga di jadikan pemukiman pada tepiannya, khususnya masa Kesultanan dan Kolonial, adapun pemukiman masa Kesultanan yang hingga sekarang masih ada seperti Kampung Arab Almunawar, dan pemukinan masa Kolonial seperti Kampung Kapitan.

Benda-benda peninggalan sejarah yang di temukan di Sungai Musi pada masa Kerajaan Sriwiaya banyak berupa benda-benda yang terbuat dari timah dan tanah liat. Benda benda yang terbuat dari timah diantaranya, yaitu pedang naga Sriwijaya, surat timah, uang barang perahu dan bambu, dan barang yang terbuat dari tanah liat diantaranya seperti keramik berbentuk guci, kendi tarakota, dan manikmanik yang berwarna cokelat, untuk manik-manik yang berwarna-warni seperti hijau, biru, merah dan kuning terbuat dari kaca. Selain itu juga diemukan baru gambar, dan cermin perunggu. Benda-benda masa Kesultanan yang 
HISTORIA: Jurnal Pendidik dan Peneliti Sejarah, 5(1), 65-80. https://doi.org/10.17509/historia.v5i1.36374.

ditemukan, yaitu berupa golok, keramik berbentuk guci, uang koin. Dan pada masa kolonial benda yang di temukan berupa koin yang terbuat dari logam, wadah tinta, botol jamu dan juga botol alkhohol yang terbuat dari tanah liat yang diproses dengan pembakaran tinggi. Setiap benda yang ditemukan memiliki nilai yaitu nilai sejarah dan budaya, politik dan kekuasaan, perjuangan dan kekuatan, ekonomi dan teknologi, serta nilai estetika atau keindahan.

Penerapan benda-benda peninggalan sejarah di Sungai Musi sebagai sumber pembelajaran sejarah memiliki respon yang baik oleh guru dan siswa kelas X di SMK Negeri 2 Palembang. Menurut guru mata pelajaran sejarah di SMK Negeri 2 Palembang materi yang penulis berikan berkaitan dengan materi pembelajaran pada silabus kurikulum k-13 yang terdapat dalam KD 3.3, 3.4, dan 3.5 mengenai masa Hindu Budha di Indonesia, Masa Islam, dan Kolonialisme. Sehingga materi Peninggalan benda-benda sejarah yang ditemukan di Sungai Musi dapat diterapkan sebagai sumber pembelajaran di SMK Negeri 2 Palembang pada kelas X.

\section{REFERENSI}

Ainina, I. A. (2014). Pemanfaatan media audio visual sebagai sumber pembelajaran sejarah. Indonesian Journal of History education, 3(1), 40-45.

Anggito, A., \& Setiawan. (2018). Metodologi penelitian kualitatif. CV Jejak.

Anonim. (2016, Juli 15). edel.staff.unja. Retrieved from edel.staff.unja.ac.id: http://edel.staff.unja.ac.id/blog/ artikel/Pengertian-Media-Pembelajaran.html

Burhanuddin, S. (2003). Sejarah maritime indonesia: menelusuri jiwa bahari bangsa indonesia dalam proses integrasi bangsa (sejak jaman prasejarah hingga abad $x v i i)$. KPP-Balitbang.

Bungin, B. (2007). Penelitian kualitatif komunikasi, ekonomi, kebijakan publik, dan ilmu sosial lainnya. Kencana.

Farida. (2020). Sungai musi sebagai pertahanan bagi kesultanan palembang. Jurnal Tuah Vol 1, 54-66.

Farida, I., Rochmiatun, E., \& Kalsum, N. U. (2019). Peran sungai musi dalam perkembangan peradaban islam di palembang: dari masa kesultanan sampai hindia belanda. IUSPI (Jurnal Sejarah Peradaban Islam), $3(1), 50-57$.

Gunawan. (2013). Metode penelitian kualitatif. UM Press.

Hamalik, O. (2010). Kurikulum dan pembelajaran. Bumi Aksara.

Handayani, I. R. (2013). Penggunaan media kartu bergambar untuk meningkatkan hasil belajar peninggalan sejarah pada kelas vi di minu curungrejo kepanjen. Doktoral dissertation, Universitas Islam Malik Maulana Malik Ibrahim.

Hasan, S. H. (2019). Pendidikan Sejarah Untuk Kehidupan Abad Ke 21. Historia: Jurnal Pendidikan dan Peneliti Sejarah, 2(2), 61-72.

Husnul, H. (2014). Konteks Ekologi Kota Tepian Sungai dalam Perspektif Lokalitas Bahan Bangunan. Architecture Event 2014-Membangun Karakter Kota Berbasis Lokalitas, 3-77.

Khoiri. (2017). Tahap-Tahap Penelitian Kualitatif. Yogyakarta: Balai Pustaka.

Khoirotun. (2014). Perencanaan Buku Pop-Up Museum Sangiran Sebagai Media Pembelajaran Peninggalan Sejarah. Surabaya: Doctoral dissertation, STIKOM Surabaya.

Khoirotun, A., Fianto, A. Y., \& Riqqoh, A. K. (2014). Perencanaan buku pop-up museum Sangiran sebagai media pembelajaran tentang peninggalan sejarah. Jurnal Art Nouveau, 2(1), 134-141.

Kochhar, S. K. (2008). Pembelajaran sejarah. PT. Grasindo.

Majid, A. (2008). Perencanaan pembelajaran, mengembangkan standar kompetensi guru. PT. Rosda Karya.

Mahmud, K. I. (2008). Sejarah palembang. Palembang: Anggrek.

Mas'oed, K. A. (1941). Sedjarah palembang moelai sedari seri-widjaya sampai kedatangan balatentara dai nippon. Meroeyana.

Novitasari, \& Hanif, M. (2017). Tari kecetan dalam tradisi keduk beji desa tawun kecamatan kasreman kabupaten ngawi (makna simbolis dan sumber pembelajaran sejarah lokal). Agastya: Jurnal Sejarah dan Pembelajarannya Vol. 7 (1).

Pradhani, S. I. (2017). Sejarah hukum maritim kerajaan sriwijaya dan majapahit dalam hukum indonesia kini. Lembaran Sejarah, 13(2), 186-203.

Prakoso, A. A. (2018). Arahan pengembangan kawasan wisata sungai musi kota Palembang. Jurnal Arsitektur dan Perencanaan (JUARA), 1(1), 1-13.

Rishky. (2013, Juli 17). Peninggalan sejarah. Retrieved from SlideShare: https://www/slideshare.net/mobile/ rishky/peninggalan-sejarah

Ryan, P. A., Akbar, M., \& Andryani, R. (2016). Sistem informasi e-museum sebagai media penyajian informasi benda-benda sejarah dan budaya di sumatera selatan. Tersedia online. http://eprints. binadarma.ac.id/2984/1/SHM201603-12141185.pdf

Sanjaya, W. (2006). Strategi pembelajaran berorientasi standar proses pendidikan. Prenada Media Grub. 


\section{Liamilatul Rohmah, Kabib Sholeh, Wandiyo Wandiyo}

Santun, D. I. (2010). Venesia dari timur: memaknai produksi dan reproduksi simbolik kota palembang dari kolonial sampai pascakolonial. Ombak.

Saputra, A., \& Hasan, Y. (2014). Kerjasama kerajaan sriwijaya dengan dinasti tang pada tahun 683-740 m. Jurnal Pendidikan Sejarah, 3(2), 62-67.

Sholeh, K. (2017). Prasasti talang tuo peninggalan kerajaan sriwijaya sebagai materi ajar sejarah indonesia di sekolah menengah atas. Historia, 5(2), 177-178.

Sholeh, K., \& Nindiati, D. S. (2018). Eksisitensi jembatan ampera terhadap perkembangan sosial, budaya, dan ekonomi masyarakat ulu palembang tahun 19502010. Jurnal Historia, 6(2), 273-294.

Sholeh, K., Sari, W. N., \& Berliani, L. (2019). Jalur pelayaran perdagangan kuno di selat bangka sebagai letak strategis berkembangnya kekuasaan maritim sriwijaya abad vii-viii masehi. SINDANG: Jurnal Pendidikan Sejarah Dan Kajian Sejarah, 1(1), 25-34.

Sholeh, K. (2018). Masuknya agama islam di palembang pada masa kerajaan sriwijaya abad vii masehi. In prosiding seminar nasional program pascasarjana universitas pgri Palembang, 5(5), 207-214.

Slameto. (1991). Proses belajar mengajar dalam sistem kredit semester. Bumi Aksara.
Subadyo, T. (2012). Optimasi potensi artefak budaya pada masa koridor sungai musi untuk pengembangan wisata sejarah di kota palembang. Journal of Architecture and Wetland Environment Studies, 1(1).

Sugiyono. (2015). Metode penelitian pendidikan pendekatan kuantitatif, kualitatif, dan red. Alfabeta.

Sugiyono. (2017). Metode penelitian kuantitatif, kualitatif, dan red. Alfabeta.

Susanto, H., \& Akmal, H. (2019). Media pembelajaran sejarah era teknologi informasi. Program Studi Pendidikan Seajarah FKIP Universitas Lambung Mangkurat.

Suyadi. (2013). Strategi pembelajaran pendidikan karakter. PT Remaja Rosdakarya.

Utomo, B. B. (2015). Diplomasi kebudayaan cheng ho di nusantara abad ke 15 masehi.

Wicaksono, B., \& Kusdiwanggo, S. (2016). Modus bermukim masyarakat riparian sungai musi palembang. Historical Continuity for Sustainable Future, 11-20.

Warsita, B. (2008). Teknologi landasan pembelajaran dan aplikas. Rineka Cipta.

Wartha, I. B. (2016). Manfaat penting "benda cagar budaya" sebagai peninggalan sejarah / arkeologi untuk kepentingan agama, sosial budaya, sosial ekonomi, pendidikan dan ilmu pengetahuan. Jurnal Santiaji Pendidikan, 6(2), 189-196. 